\title{
The suffering of a victim of child sexual abuse
}

\author{
Norhidayah Daud ${ }^{1}$, Faizah Abd Ghani ${ }^{\left.{ }^{*}\right)}$ \\ ${ }^{1}$ Universiti Tekonologi Malaysia, Malaysia
}

\begin{tabular}{|c|c|}
\hline Article Info & ABSTRACT \\
\hline Article history: & Stressful early life experiences may cause traumatic experience across the \\
\hline $\begin{array}{l}\text { Received Sep } 19^{\text {th }}, 2020 \\
\text { Revised Oct } 28^{\text {th }}, 2020 \\
\text { Accepted Nov } 25^{\text {th }}, 2020\end{array}$ & $\begin{array}{l}\text { lifespan. The aim of this study was to explore a CSA female victim's lived- } \\
\text { experience. Interviews were conducted with this } 13 \text {-year-old girl, N, using a } \\
\text { case study approach. } \mathrm{N} \text { was still a young child (seven years old) when her } \\
\text { uncle started to rape her, and when she was } 10 \text { years old, her father raped her. } \\
\text { Since her childhood, she has experienced complex and widespread }\end{array}$ \\
\hline Keyword: & $\begin{array}{l}\text { consequences such as vaginal and abdominal pain, shivering, sleeping } \\
\text { problems, digestive problems, back problems, emotional and cognitive }\end{array}$ \\
\hline $\begin{array}{l}\text { Child sexual abuse } \\
\text { Case study }\end{array}$ & $\begin{array}{l}\text { problems such as she was thinking to commit suicide, scared that her uncle } \\
\text { and father will come to her, dissociation, study problems and isolation. N's } \\
\text { situation, might reflect similar problems in, other female CSA victims. }\end{array}$ \\
\hline
\end{tabular}

(C) 2020 The Authors. Published by Redwhitepress.

This is an open access article under the CC BY-NC-SA license (https://creativecommons.org/licenses/by-nc-sa/4.0/

\section{Corresponding Author:}

Faizah Abd Ghani,

Universiti Teknologi Malaysia

Email: faizah-ag@utm.my

\section{Introduction}

All of us assimilate knowledge all through our lives. It begins from the moment people are born into this world. The earliest years of lifespan are the utmost consequential for knowledge. That is when the fundamentals knowledge for the future are placed, and when we commence in moving to the path that will bring us through childhood, the youth years and eventually into adulthood.

According to Zahyah (2008), in order for the children to experience a healthy growth, psychological and sociological aspects of the children should be filled. In addition, according to Shonkoff and Philipp (2000) and Phillips, McCartney and Sussman (2006), for individual's success in school, workplace and community, the emotional and physical health, social skills and cognitive-linguistic capacities that arise during childhood years are crucial. To add, science shows on the requirement of a children including on the things they need to be protected from, in order to encourage their healthy development. In order to provide lifelong benefits for behavior and both physical and mental health, the children need a stable, responsive, nurturing relationships and rich healthy learning experiences during their childhood years (Shonkoff \& Richmond, 2009).

However, in contrast, research on the biology of stress in early childhood illustrates that chronic stress affected by major difficulties, such as extreme poverty, abuse or neglect will affect to a weak developing brain architecture and eternally on the individual body's stress response system, thus making the individual to expose for a risk for chronic diseases (Shonkoff \& Phillip, 2000). Other than that, according to Shonkoff, Boyce and McEwan (2009), when children experienced extreme, regular or continued harmful experiences such as repeated abuse alone without support from adults, the stress that they feel will eventually become toxic thus affect their brain development as well as physical and mental health. Shonkoff, Boyce and McEwan, (2009) adds, more harmful experiences in childhood will affect to the greater developmental difficulties and 
other problems may happen. This was seen in a research by Shonkoff, Boyce and McEwan (2009) which revealed that adults who have chronic health problems such as depression, alcoholism and heart disease are the one who had more negative experiences during their early childhood.

As stated above, repeated abuse may cause toxic stress to the children and sexual abuse is one type of abuse that the children experienced in which considered as a harmful experience (Nor Shafrin, 2007). In recent years, the cases of child sexual abuse are alarming as based on National Society for the Prevention of Cruelty to Children (NSPCC), around a quarter of adolescents (24.1\%) experienced sexual abuse, whether contact or non- contact by an adult or peers during childhood (Redford et al, 2011). Whereby, in Malaysia, even though Child Act 2001 has been developed to protect the children, the number of child sexual abuse is getting higher and alarming. A report by BERNAMA (2017) stated that statistic from the Malaysia Department of Social Welfare showed that from 2010 to 2015 there were 5,779 cases of child sexual abuse were recorded, with an average case of 963 cases per year. Meanwhile, statistics from Royal Malaysian Police (PDRM) logged 412 incest cases and 2,759 rape cases in 2015 and 2016 involving victims under 18 years (Ministry of Communication \& Multimedia Malaysia).

With the alarming cases of Child Sexual Abuse (CSA) in Malaysia, therefore it is a need of a research to be done to explore the issue and to impart the knowledge and awareness to the society on the reality and phenomenon of CSA among children in Malaysia. The objectives of this study are: 1) To explore the background of the victims of child sexual abuse; 2) To explore the chronology of child sexual abuse of the victims; 3) To explore the effect(s) of child sexual abuse to the victim.

\section{Literature Review}

The most recent study was conducted by Sigurdardottir \& Halldorsdottir (2018). This study is a case study of a 40 years old woman who have experienced child sexual abuse since she was 2 years old. This phenomenological approach of study aimed to see female child sexual abuse survivor's lived-experience of the physical health, affected by the traumatic sexual abuse she had experienced. Seven interviews were done and the findings show that since her childhood, she has experienced mind boggling and far reaching physical wellbeing results, for example, rehashed vaginal and stomach diseases, resting issues, stomach related issues, incessant back issues, fibromyalgia, musculoskeletal issues, rehashed urinary tract contaminations, cervical dysplasia, aggravation of the fallopian tubes, menorrhagia, endometrial hyperplasia, chlamydia, ovarian growths, ectopic pregnancies, uterus issues, extreme grips, and ovarian malignancy.

Another recent study on child sexual abuse was conducted in Indonesia by Handani, Nursyirwan, Rizanda \& Artha Budi (2018), by using case study approach. This study aimed to describe the dynamic and psychological impact on the child after experiencing sexual abuse. The samples of this study were the victims, the perpetrator, and the victim's parents, and the supporting informants were the teacher and psychologist. Data collection technique was carried out by in-depth interviews, observation, and document study. The results of this study showed that the psychological dynamics of victims of child sexual abuse had the same pattern. Characteristics of victims who were quiet and introvert, and families who lack of supervision and protection of the subject, both influenced each other against the occurrence of child sexual violence and made the victim had a traumatic experience.

There are several studies done in Malaysia. One of the studies was conducted by Muhammed Sharif \& Nur Diyana (2012). The aim of this study was to investigate the psychological effects experienced by the victims as the effect of sexual abuse. This was a case study, with five respondents. The findings suggested that the level of psychological effects and adaptation of the victims were at high level, but the supports and help that they receive was at low level.

Another prominent recent study in Malaysia on child sexual abuse was conducted by Nor Shafrin (2007). This study was aimed to identify the level of depression of victims of child sexual abuse and the indicators of behavior showed by them. Seven respondents were asked to answer Beck Depression Inventory and interview. The findings demonstrate that all the victims suffered critical depression. The indicators of behavior shows were stressful, irritated and angry, played truant, could not focus at school, has learning difficulties, sleeping and eating disorders and attempted suicidal.

\section{Method}

This study is a case study. A case study method was applicable for this study because according to Creswell (2012), case study is an in-depth exploration of a bounded system such as activity, event, process or individuals, and this is what researcher is aimed to; to explore the traumatic experience of victims of child 
sexual abuse. Other than that, Yin (1998) defines case study as an empirical inquiry that investigates a contemporary phenomenon within its real-life context, especially when the boundaries between phenomenon and context are not clearly evident. Gerring (2004) adds, case study represents an intensive analysis of a case, due to in -depth inquiry of the case. It is rich in detail, so it allowed an in-depth analysis of the respondents which are victims of child sexual abuse. In addition, Erickson (1986) demonstrates that case study generally lies in the particular (case), and what we learn in a particular case can be transferred to similar situations.

Specifically, the type of case study of this research is an exploratory with a single case study, which is focusing on the victim of child sexual abuse in Malaysia. According to Yin (2014), exploratory case study usually focuses on a single case or limited number of cases, and the purpose is to better understand an emerging phenomenon and/or to propose new theoretical or insights to generate new. The exploration is on the background of the victims, the patterns of CSA, the factors that influence the sexual abuse experienced by the victims and the effects of sexual abuse that the victims face. This study used purposive sampling in selecting the participants. According to Patton (2002), purposeful sampling is a technique widely used in qualitative research for the identification and selection of information-rich cases for the most effective use of limited resources. This involves identifying and selecting individuals or groups of individuals that are especially knowledgeable about or experienced with a phenomenon of interest which is the victim of child sexual abuse.

This research use interview as the main instrument because it opens up broader worlds to understand the richness of the participants' experiences. Thus, interview is an excellent way to explore complex feelings and attitudes of people (Shaughnessy, Zechmeister, \& Zechmeister, 2012). This research used semi-structured interview as it allows the interviewer to be prepared and appear competent during the interview. The interview questions were developed by the previous theories which are Briere Trauma Model and Structural Model of Child Well-being by Minkkinen, along with literature reviews on the topic chosen. For analysis data, researcher will be using Nvivo software, following the thematic analysis method for all the data recorded.

\section{Results and Discussions}

\section{Background of the CSA Victim}

$\mathrm{N}$ is a thirteen-years old teenage girl. Physically, she is a chubby girl, with medium height and has a lovely smile. She has four siblings and she is the second child, the only female among them. Her father is a drug addict and because of the drug, he is a hot-temper. He does not have permanent job and always has issues in workplace. In addition, according to $\mathrm{N}$, her mother loves her family so much. She is a hardworking and lovely person. Her parents always quarrel and her father had beaten her mother few times. Socio-economy status of this family is very low and $\mathrm{N}$ always begging her relatives for food. She even searched foods from the dustbin.

"...my father is a drug addict.. he was grumpy..."

"...sometimes, I asked food from relatives.. I even searched for foods from the dustbin.."

\section{Chronology of CSA of the Victim}

$\mathrm{N}$ had gone through traumatic CSA experience since she was seven-years old. Her uncle lived with her family, and always drunk. The house has only one room and it belongs to her parent. She slept with her siblings and uncle at the living room. At one time, when nobody is awake, her drunk uncle gone up on her body, put her pants off and raped her. Her mouth was shut and she could not fight back. It continued to more than ten times. She was given RM1 or RM2 for each time she was raped. At that time, she did not understand on her experience of being 'raped', and that it was against law and should be reported. Only when she was eight years old she knew the truth when she learned about the differences between male and female. Then, she told her parent, but her father did not trust her story. Her mother put a video recorder in the living room to record any incident if that happened. It was recorded, that N's uncle was trying to rape N, but N ran into her parent's room. Her mother made a police report and her uncle was caught and jailed, but only for seven days. She does not know her uncle's whereabout now, but still afraid that he will search her.

"..i was sleeping.. my uncle up on my body, off my pants and raped me..." ".. it was hurt.."

".. at that time, I did not know that I was raped, because I don't understand. I just knew that was inappropriate."

Then, she and her family moved to another house. When she was ten years old, she was raped by her father. Her father was a drug addict and liked to watch porn. Her father raped her whenever he got a chance, to the extent whenever her mother went to toilet, for a while. $\mathrm{N}$ was scared to tell anybody about this because her father was a hot-tempered man, who used to beat-up whoever go against him. Her father warned her not to tell her mother about this, and the abuse continued until she was 12 years old. Since she was raped by her father, she had become passive and loved to isolate herself from her friends at school. The changes on her 
behaviour had been recognized by her teacher, thus medical check-up and police report were made.

".....my father raped me when he had chance. Even when my mother went to toilet for 5 minutes only.."

\section{Effects of Child Sexual Abuse (CSA) to the Victim}

Based on the story by $\mathrm{N}$, she has faced and still facing lots of effects of CSA, until now. The effects were physiology, emotion, cognition and behavior. Below is the table of the effects experienced by $\mathrm{N}$.

Table 1. The Effects of CSA to $\mathrm{N}$

\begin{tabular}{|c|c|c|}
\hline No & Effects & Interview statement \\
\hline 1 & Body pain & $\begin{array}{l}\text { "Yes, after get raped, my body was really hurts, even now.. I can still feel the pain.. I } \\
\text { don't know.." }\end{array}$ \\
\hline 2 & Vaginal pain & "It was hurt during urination.. at the vaginal part.. it was really hurt!!.." \\
\hline 3 & Shivering & $\begin{array}{l}\text { "after get raped I always shivering even now when I recalled the incident, I will } \\
\text { shiver.." }\end{array}$ \\
\hline 4 & Sleep disorder & "yes, I feel hard to sleep" \\
\hline 5 & Nightmare & "...yes..I had nightmare" \\
\hline 6 & Eating disorder & "sometimes.. yes.. I lost my appetite.." \\
\hline 7 & Thinking that she was useless & "yes.. always.. I think that I am useless.." \\
\hline 8 & Thinking to harm herself & "sometimes, I have thought to harm myself" \\
\hline 9 & Thinking that all men evil & "...yes I have a thought that men are all evils just like my uncle and father.." \\
\hline 10 & $\begin{array}{l}\text { Thinking that all men cannot be } \\
\text { trusted }\end{array}$ & "I always thinks men cannot be trusted \\
\hline 11 & $\begin{array}{l}\text { Always think that her uncle } \\
\text { and father will come back to her }\end{array}$ & $\begin{array}{l}\text { ".I always think uncle and father will come back to me.. but I don't know } \\
\text { where they are now" }\end{array}$ \\
\hline 12 & Do not trust other people & $\begin{array}{l}\text { "I have feeling that I cant trust other people..because my own family raped } \\
\text { me.." }\end{array}$ \\
\hline 13 & $\begin{array}{l}\text { Difficulties in making } \\
\text { friends }\end{array}$ & "definitely..I feel hard to make friends.." \\
\hline 14 & Unfriendly friends & $\begin{array}{l}\text { "when I was at school, I was not friendly with my friends and my teacher } \\
\text { noticed it.." }\end{array}$ \\
\hline 15 & $\begin{array}{l}\text { Doing something out of } \\
\text { control }\end{array}$ & $\begin{array}{l}\text { "...suddenly I feel like running away from one plave or one situation. the } \\
\text { feeling was uncontrollable" }\end{array}$ \\
\hline 16 & Self-isolation & "I like to be with myself alone..just myself" \\
\hline 17 & Do not want to be disturbed & "I don't like to be disturbed" \\
\hline 18 & Harming other people & "I beat people when I was angry" \\
\hline 19 & Cannot focus during study & "It is hard to focus in study" \\
\hline 20 & $\begin{array}{l}\text { Inflamed when playing with porn- } \\
\text { toys/games }\end{array}$ & $\begin{array}{l}\text { "Yes.. I inflamed when playing with porn toys and games.. when I was at } \\
\text { school last time.." }\end{array}$ \\
\hline 21 & $\begin{array}{l}\text { Hate for what other people } \\
\text { had done to her }\end{array}$ & "I hate for what other people had done to me I cannot forget.." \\
\hline 22 & Get sad easily & "I get sad easily" \\
\hline 23 & Get mad easily & "yes.. I get mad easily" \\
\hline 24 & Always scared & "always.. always scared" \\
\hline 25 & $\begin{array}{l}\text { Ashamed for not virgin } \\
\text { anymore }\end{array}$ & "of course I feel shame.. Ashamed for not virgin anymore" \\
\hline 26 & Mix-feeling & $\begin{array}{l}\text { "yes... mix-feeling.. sometimes I want to cry, but I laughed.. and suddenly I get } \\
\text { mad" }\end{array}$ \\
\hline 27 & $\begin{array}{l}\text { Feels that the perpetrators } \\
\text { should be punished }\end{array}$ & "...my uncle and father should be punished!" \\
\hline 28 & $\begin{array}{l}\text { Do not confident when meeting with } \\
\text { adults }\end{array}$ & "yes..I don't feel confident when meeting with adults.." \\
\hline
\end{tabular}

The table 1 shows that $\mathrm{N}$ faces various effects of child sexual abuse and she is still suffering until now. The effects varied from physiology, cognitive, emotion and behavior aspects. 


\section{Conclusions}

In conclusion, $\mathrm{N}$ is a thirteen-years old teenage girl. She has four siblings and she is the second child, the only female among them. Her father is a drug addict and because of the drug, he is a hot -temper. $\mathrm{N}$ loves her mother so much. Her mother is a hardworking and lovely person. Her parents always quarrel and her father had beaten her mother few times. Socio-economy status of this family is very low and $\mathrm{N}$ always begging her relatives for food. She even searched foods from the dustbin. $\mathrm{N}$ was raped since she was seven years old by her own drunk uncle. The incident continued until she was 8 years old. Then, at 10 years old, she was raped by her father until she was 12 years old. Her father is a drug addict. $\mathrm{N}$ had suffered and still suffering from various effects of sexual abuse. The effects are Body pain, vaginal pain, shivering, sleep disorder, nightmare, eating disorder, thinking that she was useless, thinking to harm herself, thinking that all men evil, thinking that all men cannot be trusted, always think that her uncle and father will come back to her, do not trust other people, difficulties in making friends, unfriendly with friends, doing something out of control, self-isolation, do not want to be disturbed, harming other people, cannot focus during study, inflamed when playing with porntoys/games, hate for what other people had done to her, get sad easily, get mad easily, always scared, ashamed for not virgin anymore, mix-feeling, feels that the perpetrators should be punished and do not confident when meeting with adults. The suffering that $\mathrm{N}$ faces were haunted her and she admits that she needs help to help her to encounter all the effects that she suffered from. Thus, the findings from this study are hoped will benefit other researchers in planning and developing a helping model to help victims of child sexual abuse like $\mathrm{N}$.

\section{Acknowledgments}

We are very much thankful for the grant provided by Ministry of Higher Education for this project's fund. The grant is under Fundamental Research Grant Scheme (FRGS): Cost Center No R.J130000.7831.4F977. We also would like to extend our gratitude to UTM, KPWKM, JKM and all the parties involved in the completion of this project.

\section{References}

Cresswell JW. (2012). Educational Research: Planning, Conducting and Evaluating Quantitative and Qualitative Research. 4th Edition Pearson; University of Nebraska-Lincoln

Erickson, F. (1986). Qualitative methods in research on teaching. In M.C. Whittrock (Ed.), Handbook of research on teaching. (3rd ed.) (pp. 119-161). Old Tappan, NJ: Macmillan.

Handayani1 , Nursyirwan Effendi2, Rizanda Machmud3, Artha Budi Susila Duarsa. (2018). A Case Study of Child Sexual Abuse: Psychological Dynamic. Child Sexual Abuse: Vol. 12, NO. 4, OCT - DEC 2018

Muhamed Sharif Mustaffa \& Nur Diana Abd Rahim (2012) Kesan Psikologi dan Bentuk Sokongan Anak Deraan Seksual. Journal of Education Psychology \& Counseling. Volume 6 June 2012, Pages 30-49

Nor Shafrin Ahmad. (2007). Mengenalpasti Indikator Tingkahlaku Mangsa Penderaan Seksual. Jurnal Pendidikan, Jil 22, 107-125, 2007

Patton MQ. (2002). Qualitative research and evaluation methods. 3rd Sage Publications; Thousand Oaks, CA Phillips, D., McCartney, K., \& Sussman, A. (2006). Child Care and Early Development. In K. McCartney \&

D. Phillips (Eds.), Blackwell handbooks of developmental psychology. Blackwell handbook of early childhood development (p. 471-489).

Radford, L. et al (2011) Child abuse and neglect in the UK today. London: NSPCC

Shaughnessy, J. J., Zechmeister, E. B., \& Zechmeister, J. S. (2012). Research Methods in Psychology. Research methods in psychology (Ninth). McGrawHill

Shonkoff J.P \& Richmond J.B. (2009). Investment in early childhood development lays the foundation for a prosperous and sustainable society. In: Tremblay RE, Boivin M, Peters RDeV, eds. Encyclopedia on

Early Childhood Development [online]. Montreal, Quebec: Centre of Excellence for Early Childhood Development and Strategic Knowledge Cluster on Early Child Development; 1-5. Available at http://www.childencyclopedia.com/documents/ShonkoffANGxp.pdf.

Shonkoff JP \& Richmon, JB .(2009). Investment in early childhood development lays the foundation for a prosperous and sustainable society. In: Tremblay RE, Boivin M, Peters RDeV, eds. Encyclopedia on Early Childhood Development [online]. Montreal, Quebec: Centre of Excellence for Early Childhood Development and Strategic Knowledge Cluster on Early Child Development; 2009:1-5. Available at: http://www.childencyclopedia.com/documents/ShonkoffANGxp.pdf 
Shonkoff, J. P. \& Phillips, D.A. (2000). From Neurons to Neighborhoods: The Science of Early Childhood Development. Washington, DC: National Academy Press.

Shonkoff, J. P., Phillips, D. A. (Eds.). (2000). From neurons to neighborhoods: The science of early childhood development. Washington, DC: National Academies Press.

Sigurdardottir, S. \& Halldorsdottir, S. (2018). Screaming Body and Silent Healthcare Providers: A Case Study with a Childhood Sexual Survivor. International Journal of Environmental Research and Public Health. 15(1):94

Yin, R.K. (1998). Case Study Research: Design and Methods, Second Edition. USA: SAGE Publication

Yin. R.K. (2014). Case Study Research Design and Methods (5th ed.). Thousand Oaks, CA: Sage. 282 pages.. The Canadian Journal of Program Evaluation. 10.3138/cjpe.30.1.108.

Zahyah Hanafi. (2008). Teori Pembangunan Kanak-kanak. Pembangunan Kanak-kanak: Teori, Isu dan Cabaran Selangor: Arah Pendidikan Sdn Bhd 